\title{
Cultural Pluralism in a Globalised World: Challenges to Peaceful Coexistence
}

\author{
Osman Bakar*
}

In the following paragraphs I would like to highlight the impact of globalisation on cultural pluralism and then the issue of how the resulting cultural pluralism might in turn impact the future pattern of the world order. The thrust of my theme is on emphasising the need to better understand the meaning and implications of the changing face of cultural pluralism for our contemporary world. It is also to suggest what we need to do to effectively confront the major challenges posed by the cultural pluralism landscape of our early twenty-first century. In hammering home my points I will take Malaysia as an example, which itself was created out of the cultural pluralism unleashed by the European wave of globalisation during the colonial era. Malaysia is today a Muslim-majority country with a large non-Muslim population thanks largely to what I have termed as demographic globalisation. With all the major religions of the world each having a good number of followers in the country Malaysia is truly a multi-religious society. It is also a good example of a truly multi-ethnic country boasting of dozens of ethnic groups. For more than 50 years now Malaysia has been struggling to create a pluralistic and yet united modern nation out of its ethnic, religious, and cultural diversity. Its successes and failures are all there for everyone to see.

\section{Our World: More Globalisation, not Less}

Without doubt we live today in a world which is increasingly globalised. No matter how we define globalisation it is true to say that our world of today is more globalised than our world of say only a few decades ago, let alone of a century ago. We can say with confidence that our world of tomorrow will be more globalised than our world of today. There is a good explanation why this phenomenon of progressive globalisation is happening to our world. A powerful combination of material and human factors, especially those pertaining to communications and transportation technology, economic interdependence, and education help to guarantee the momentum of our world moving in the direction of greater globalisation. These three main factors have resulted in an unprecedented flow and

* Prof. Emer. Dr Osman Bakar is the Deputy CEO of IAIS Malaysia. This contribution was delivered by him as a lecture at the Second International Conference on "New Horizons in Islamic Area Studies" (Cairo University, 12-13 December 2009) and has been adapted for publication in this journal's viewpoint section. 
movement of people across national boundaries and across continents that help to bring about far-reaching changes to the demographic and cultural map of the world. In order to better understand the irreversibility of this direction we need to look at the nature of globalisation itself.

Globalisation has been understood and defined in many different ways. The popular understanding of it is unfortunately but understandably limited to its economic and financial dimension. In reality, however, globalisation as a whole refers to a much broader, more comprehensive, and more complex phenomenon shaping our contemporary world. No matter how important the economic and financial transformation of our world is to our understanding of globalisation we need to see and understand it for what it is. As I seek to define it, globalisation is a multi-dimensional process embracing at least six major dimensions of human life and thought, namely, the economic (including the financial), the political, the religious and cultural, the scientific, the technological, and the demographic. The multi-dimensional nature of globalisation should be obvious to us when we can see very clearly the different kinds of objects that are being globalised, both material and intangible. As a process, globalisation involves the interrelated flows on a global scale of such things as goods, services, money, people, information and technological skills as well as less tangible things such as ideas, values, behavioural norms and cultural practices across state and national boundaries either in ways that are planned and regulated or otherwise.

Globalisation is therefore to be seen as a dynamic process in which the global human community is becoming more and more interconnected and interdependent as a result of the complex interplay of various kinds of forces, both natural and human, associated with each of the six dimensions to which I have referred. It is also a global process in which both unity and diversity in human life and thought are becoming more visible than ever before.

Several assertions can be made: First, it is meaningful to speak of the different kinds of globalisation, namely, economic and financial globalisation, political globalisation, religious and cultural globalisation, scientific globalisation, technological globalisation, and demographic globalisation. We may therefore speak of globalisation both in the singular and in the plural. Globalisation in the plural refers to its different dimensions I have listed. And globalisation in the singular refers to the overall process in which these different dimensions interact with one another to produce progressive interconnectedness and interdependence in the global human community.

Second, we may claim that it is in the nature of this multi-dimensional globalisation to display increasing interconnectedness and interdependence in the world community as a clear manifestation of its underlying unity hand in hand 
with increasingly problematic religious and cultural encounters between its diverse components as a clear sign of its poorly managed diversity.

Third, the trends observable in the globalisation process are also very clear to us. Our world is moving in the direction of greater globalisation and not less. The different parts of the world which used to be separated from each other in the past by both geographical and cultural distances are now moving closer to the emergence of a single global human community. The idea of our world becoming a global village, once a much talked about topic, may still serve as a potent reminder of the strong belief among many people in the irreversibility of globalisation. If we are looking for a deeper reason for this irreversibility then we may be able to find it in the fact that this globalisation is essentially knowledge-based. The scientific and technological globalisations are two major components of this knowledge-based globalisation that by their very nature would help to ensure its irreversibility. Scientific and technological knowledge is accumulative by nature. It is this fact more than any other which will help to produce more intensive globalisation not only within their own specific domains but also in the other four domains of economics and finance, politics, religion and culture, and demography.

\section{Effects of Globalisation on Cultural Pluralism}

The effects of globalisation in the sense I have understood it on our contemporary world both in material and human terms are numerous, diverse, and in many cases extremely challenging. Many of these are positive to the future wellbeing of humanity. But perhaps equally true are the plentiful negative effects of globalisation on our contemporary human life. Much has been spoken about and written on the virtues and vices of globalisation. While the discourse on globalisation is an ongoing thing at all levels - national, regional, and global - the different faces of globalisation are also changing. One of the most fateful consequences of globalisation is the increasingly pluralistic nature of our world. Of course, long before the modern word 'globalisation' was coined, the world as a whole has always been pluralistic in the sense of being multi-ethnic, multi-religious, multi-cultural, and multi-civilisational since the beginning of historical times. But human perceptions of this fact of plurality have not remained unchanged. We in the modern world have become more conscious than ever of the fact that we do live in a very much pluralistic world. Our new consciousness pertaining to cultural pluralism is no doubt largely due to the fact that thanks to the dominant forces shaping our contemporary globalisation - media, telecommunication and transportation technology in particular - we are able to personally observe in human societies everyone becoming more pluralistic and heterogeneous. 
We can hardly find today a culturally homogeneous society on earth any more. Malaysia is in a good position to speak about its long experience of the major 'waves of globalisation' since Islam appeared on the world scene in the seventh century CE. Malaysia - a country situated in Maritime Southeast Asia - was impacted by the Islamic wave of globalisation particularly in the thirteenth century. As a result of this wave which was mainly driven by trade and Sufi missionary activities, Malaysia and the neighbouring region were gradually transformed into Muslim-majority territories. Second, there was the impact of the European wave of globalisation unleashed primarily by colonialism. Third, there is the post-colonial (post-World War II) wave of globalisation, dominated by the United States, which we are still experiencing. All those three waves of globalisation have helped to significantly change the religious and cultural landscape of Malaysia over the centuries. Despite the large influx of migrant workers from China, India and Sri Lanka during the colonial period, Malaysia remains until today as a Muslim-majority country. However, the large non-Muslim minorities in the country (about 40 per cent) are a major legacy of the colonial wave of globalisation. Interestingly, the post-colonial wave of globalisation has had the reverse effect of bringing continuous streams of migrants, mostly Muslims, from former colonies to Europe and the United States.

\section{Addressing the Challenge of Cultural Pluralism}

While technology has helped to turn our world into a homogeneous "global village" in the material sense we find ourselves hardly ready to live in the same village in peaceful coexistence with others who are culturally different from us. But given the changing nature of our world irreversibly moving in the direction of greater and more complex pluralism we have no choice but to live with the reality which such a world would dictate upon us. We have to confront wisely and patiently the challenge of cultural pluralism. There may be many different ways of responding to this challenge. In my view, it is extremely important to highlight the importance of cultural dialogue in the pursuit of the common good as a way out of our present dilemma posed by the multi-faceted contemporary phenomenon of cultural pluralism.

The key to peaceful coexistence in a world of diversity and pluralism is the cultivation of cultural dialogue as a way of life. Through this dialogue we hope to identify our commonalities with the view of strengthening them and to identify our differences which we then seek to reduce to their irreducible levels. We then appeal to education to help us inculcate the right spirit of respect and tolerance for these irreducible differences. 